\title{
Successful cloning of an adult breeding boar from the novel Chinese Guike No. 1 swine specialized strain
}

\author{
Jun-yu Nie ${ }^{1} \cdot$ Xiang-xing Zhu ${ }^{1} \cdot$ Bing-kun $\mathrm{Xie}^{2} \cdot$ Su-qun Nong ${ }^{2} \cdot$ Qing-yan $\mathrm{Ma}^{2} \cdot$ \\ Hui-yan $\mathrm{Xu}^{1} \cdot$ Xiao-gan Yang ${ }^{1}$ Y Yang-qing $\mathrm{Lu}^{1} \cdot$ Ke-huan $\mathrm{Lu}^{1} \cdot$ Yu-ying Liao ${ }^{2}$. \\ Sheng-sheng $\mathrm{Lu}^{1}$
}

Received: 11 August 2016/Accepted: 15 September 2016/Published online: 8 October 2016

(c) The Author(s) 2016. This article is published with open access at Springerlink.com

\begin{abstract}
Somatic cloning, also known as somatic cell nuclear transfer (SCNT), is a promising technology which has been expected to rapidly extend the population of elaborately selected breeding boars with superior production performance. Chinese Guike No. 1 pig breed is a novel swine specialized strain incorporated with the pedigree background of Duroc and Chinese Luchuan pig breeds, thus inherits an excellent production performance. The present study was conducted to establish somatic cloning procedures of adult breeding boars from the Chinese Guike No. 1 specialized strain. Ear skin fibroblasts were first isolated from a three-year-old Chinese Guike No. 1 breeding boar, and following that, used as donor cell to produce nuclear transfer embryos. Such cloned embryos showed full in vitro development and with the blastocyst formation rate of $18.4 \%$ (37/201, three independent replicates). Finally, after transferring of 1187 nuclear transfer derived embryos to four surrogate recipients, six live piglets with normal health and development were produced. The overall cloning efficiency was $0.5 \%$ and the
\end{abstract}

J. Nie, X. Zhu and B. Xie contributed equally to this work.

Yu-ying Liao

315951610@qq.com

$\triangle$ Sheng-sheng Lu

shengshenglu@sina.com

1 State Key Laboratory for Conservation and Utilization of Subtropical Agro-Bioresources, Guangxi High Education Key Laboratory for Animal Reproduction and Biotechnology, College of Animal Science and Technology, Guangxi University, Nanning 530004, China

2 Guangxi Key Laboratory of Livestock Genetic Improvement, Guangxi Institute of Animal Sciences, Nanning 530001, China clonal provenance of such SCNT derived piglets was confirmed by DNA microsatellite analysis. All of the cloned piglets were clinically healthy and had a normal weight at 1 month of age. Collectively, the first successful cloning of an adult Chinese Guike No. 1 breeding boar may lay the foundation for future improving the pig production industry.

Keywords Cloning - Adult breeding boar - Chinese Guike No. 1 pig breed $\cdot$ Swine specialized strain $\cdot$ Pig production industry

\section{Introduction}

Somatic cloning, also known as somatic cell nuclear transfer (SCNT), is a promising technology which can be simply summarized as that transferring the nucleus of a somatic cell into an enucleated oocyte to reconstruct a new embryo, which can then be transplanted into a surrogate mother to generate an offspring (Wilmut et al. 2002; Gurdon and Wilmut 2011). In theory, using somatic cells from a live animal, SCNT technique can be used to produce a large number of offspring with exactly the same genetic makeup from the donor animal. Therefore, since the first batch of cloned pigs generated by SCNT in 2000 (Betthauser et al. 2000; Onishi et al. 2000; Polejaeva et al. 2000), such technique has been expected to rapidly extend the population of elaborately selected breeding boars with superior production performance (Vajta and Gjerris 2006; Vajta et al. 2007; Whyte and Prather 2011; Galli et al. 2012; Niemann and Lucas-Hahn 2012; Lee and Prather 2013; Liu et al. 2015).

Chinese Guike No. 1 pig breed is a novel swine specialized strain generated by crossbreeding of Duroc (male 
parent) with Chinese Luchuan pig breed (female parent). The later is a unique Chinese indigenous swine breed with numerous production advantages, such as higher resistance to disease, strong adaptive capacity to environmental change, as well as has a large litter size (Fang et al. 2004; Yang et al. 2006; Wang et al. 2014). Therefore, the Chinese Guike No. 1 pig breed which is incorporated with the pedigree background of Duroc and Luchuan pig breeds, resulting in an excellent production performance. In consideration of the traditional breeding process is prolonged and money-consuming, it's expectable that somatic cloning could show its capabilities in improving the production and extension of adult Chinese Guike No. 1 breeding boars.

The present study was conducted to establish somatic cloning procedures of adult Chinese Guike No. 1 breeding boars for improving their application in pig production industry. We first isolated the ear skin fibroblasts from a three-year-old Chinese Guike No. 1 breeding boar. Cultured cells were then used as donor cells to produce cloned embryos. Such cloned embryos showed full in vitro development and with the blastocyst formation rate of $18.4 \%$ (37/201, three independent replicates). After transferring a total of 1187 nuclear transfer derived embryos to four surrogate recipients, two of them became pregnant and gave birth to six live male offspring with normal health and development were produced. The overall cloning efficiency was $0.5 \%$ and the clonal provenance of such piglets was confirmed by DNA microsatellite analysis.

In summary, in the present study, we successfully produced six healthy cloned piglets using the ear fibroblasts isolated from an adult Chinese Guike No. 1 breeding boar, laying the foundation for improving the application of such breeding boars with superior production performance in pig production industry.

\section{Materials and methods}

\section{Animal ethics}

All animal procedures used in this study were carried out in accordance with the Guide for Care and Use of Laboratory Animals $\left(8^{\text {th }}\right.$ edition, released by the National Research Council, USA) and were approved by the Institutional Animal Care and Use Committee (IACUC) of Guangxi University. One healthy adult Chinese Guike No. 1 breeding boar ( 3 years old and earmarked as \#200) was used to establish primary ear skin fibroblasts. Pig ovaries for producing in vitro maturated oocytes used as SCNT recipients were collected from a slaughterhouse in the suburban area near Nanning city, China.

\section{Reagents and chemicals}

Unless otherwise stated, all organic and inorganic reagents were purchased from Sigma-Aldrich Co. (St. Louis, MO, USA). Self-made solutions were filtered through a $0.22-\mu \mathrm{m}$ filter (Millipore, Bedford, MA, USA) and stored at $4{ }^{\circ} \mathrm{C}$ or at $-20{ }^{\circ} \mathrm{C}$ until use. Pipette tips, centrifuge tubes and petri dishes were purchased in aseptic packages and are all disposable.

\section{Preparation of nuclear transfer donor cells}

The preparation of nuclear transfer donor cells were performed as described previously (Liu et al. 2009, 2010, 2014; Zhu et al. 2014, 2016). Briefly, the ear tissue biopsy obtained from an adult Chinese Guike No. 1 breeding boar (earmarked as \#200) was washed several times with Dulbecco's phosphate-buffered saline (DPBS; Gibco, Grand Island, NY, USA) and digested in $0.25 \%$ (w/ v) trypsin-EDTA solution for $30 \mathrm{~min}$ at $37{ }^{\circ} \mathrm{C}$. Cell suspension was filtered using a $70 \mu \mathrm{m}$ nylon cell strainer (BD Bioscience, Bedford, MA, USA) and pellets were collected by $1000 \mathrm{rpm}$ centrifugation for $5 \mathrm{~min}$. Cells were seeded onto a 6-well cell culture cluster (NUNC, Shanghai, China) in cell culture medium [Dulbecco's modified Eagle medium (DMEM; Gibco) supplemented with $15 \%$ (v/v) fetal bovine serum (FBS; Gibco), $100 \mathrm{IU} / \mathrm{mL}$ penicillin $\mathrm{G}$ and $100 \mu \mathrm{g} / \mathrm{mL}$ streptomycin], then incubated at $37^{\circ} \mathrm{C}$ in a Heracell 150i incubator (Thermo Scientific, Waltham, MA, USA) with humidified atmosphere of $5 \%(\mathrm{v} / \mathrm{v}) \mathrm{CO}_{2}$ in air. The fibroblasts were passaged when the primary cells reached a confluence of 80-90\%. Cells were washed twice with DPBS after the medium was discarded, and then $0.5 \mathrm{~mL}$ trypsin was added to each well for a $5 \mathrm{~min}$ digestion. When most of the cells appeared round or floated off the wall as observed under the microscope, digestion was terminated by adding $2 \mathrm{~mL}$ of culture medium. We created a cell suspension by gently pipetting, and then cells were collected by centrifugation at $1000 \mathrm{rpm}$ for $5 \mathrm{~min}$. The supernatant was discarded, and pellets were diluted 1:3 with culture medium. Cells were then mixed well and transferred to 6-well plates. When the cells grew to 80-90\% confluence, the fibroblasts were digested and collected with freezing medium [90\% FBS plus $10 \%$ dimethylsulfoxide (DMSO)]. Finally, the fibroblasts were aliquoted into 2-mL cryogenic tubes (Kirgen, Shanghai, China) and stored in liquid nitrogen for future use.

To prepare nuclear transfer donor cells, cryo-preserved fibroblasts were thawed and cultured for 2 days, following synchronization by serum starvation (DMEM supplemented with $0.5 \%$ FBS) for $48 \mathrm{~h}$. The cells were then harvested and re-suspended with $1 \mathrm{~mL}$ micromanipulation medium (10 mM HEPES-buffered TCM-199 containing 
$0.3 \%[\mathrm{w} / \mathrm{v}]$ bovine serum albumin $[\mathrm{BSA}] ; \mathrm{pH}=7.3)$. This cell suspension was maintained at room temperature and used as nuclear transfer donor cells.

\section{Preparation of nuclear transfer recipient oocytes}

In vitro-matured porcine oocytes were used as nuclear transfer recipients and prepared according to methods described previously (Liu et al. 2014; Zhu et al. 2016). Briefly, cumulus-oocyte complexes (COCs) were aspirated from the follicles with sizes of 3-8 $\mathrm{mm}$, and washed twice in PVA-TL-HEPES medium. The COCs were transferred into $200 \mu \mathrm{L}$ drops of preheated maturation medium (bicarbonate-buffered TCM-199 supplemented with $0.1 \%$ [w/v] polyvinyl alcohol [PVA], $3.05 \mathrm{mM}$ D-glucose, $0.91 \mathrm{mM}$ sodium pyruvate, $0.57 \mathrm{mM}$ cysteine, $10 \mathrm{ng} / \mathrm{mL}$ epidermal growth factor [EGF], $0.5 \mu \mathrm{g} / \mathrm{mL}$ follicle-stimulating hormone $[\mathrm{FSH}], 0.5 \mu \mathrm{g} / \mathrm{mL}$ luteinizing hormone $[\mathrm{LH}], 0.0750 \mathrm{~g} / \mathrm{L}$ penicillin $\mathrm{G}, 0.0500 \mathrm{~g} / \mathrm{L}$ streptomycin and $10 \%[\mathrm{v} / \mathrm{v}]$ porcine follicular fluid $[\mathrm{PFF}] ; \mathrm{pH}=7.3$ ), covered with mineral oil, and then incubated for 20-22 h at $38.5^{\circ} \mathrm{C}$ in a Forma Series II water jacketed incubator (Thermo Scientific, Marietta, OH, USA) with humidified atmosphere of $5 \%(\mathrm{v} / \mathrm{v}) \mathrm{CO}_{2}$ in air. Then, the COCs were cultured for an additional $20 \mathrm{~h}$ in the same medium without the gonadotropins. Following maturation, expanded cumulus cells were removed from the oocytes by vigorous pipetting in the presence of $0.1 \%(\mathrm{w} / \mathrm{v})$ hyaluronidase. Oocytes with an evenly granulated ooplasm and an extruded first polar body were selected and placed into the micromanipulation medium drop (containing donor cells and $7.5 \mu \mathrm{g} / \mathrm{mL}$ cytochalasin B) on a $60-\mathrm{mm}$ cell culture dish (NUNC) covered with mineral oil for using as nuclear transfer recipients.

\section{Construction of cloned porcine embryos}

SCNT was performed as described previously (Liu et al. 2014; Zhu et al. 2016). Briefly, maturated oocyte was enucleated under the Nikon Eclipse Ti microscope (Nikon Instruments Inc., Tokyo, Japan) equipped with a Narishige micromanipulator (Narishige Instruments, Tokyo, Japan) by aspirating the first polar body plus a portion of the adjacent cytoplasm (presumably containing the metaphase II plate) using a sharp beveled glass pipette (WPI; Sarasota, Florida, USA) with a diameter of $20-25 \mu \mathrm{m}$. After enucleation, a donor cell was injected into the perivitelline space with care taken to maximize the amount of cell membrane contact between the donor cell and the oocyte. The fusion and activation of nuclear-transferred embryos were performed simultaneously using electrical pulses ( 2 successive DC pulses of $1.2 \mathrm{kV} / \mathrm{cm}$ for $30 \mu \mathrm{s}$ ) under an ECM 2001 electro cell manipulator (BTX Inc., San Diego, CA, USA) in a fusion medium (0.3 M Mannitol, $1.0 \mathrm{mM}$ $\mathrm{CaCl}_{2} \cdot 2 \mathrm{H}_{2} \mathrm{O}, 0.1 \mathrm{mM} \mathrm{MgCl} 2 \cdot 2 \mathrm{H}_{2} 0,0.5 \mathrm{mM}$ HEPES plus $0.3 \%[\mathrm{w} / \mathrm{v}] \mathrm{BSA} ; \mathrm{pH}=7.3$ ). Fusion was checked at 40-60 min later, and fused embryos were treated with $7.5 \mu \mathrm{g} / \mathrm{mL}$ cytochalasin $\mathrm{B}$ for $3 \mathrm{~h}$ to suppress extrusion of the pseudosecond polar body. After that, the reconstructed embryos were placed into Porcine Zygote Medium-3 (PZM-3) containing $0.3 \%(\mathrm{w} / \mathrm{v}) \mathrm{BSA}$ and cultured at $38.5{ }^{\circ} \mathrm{C}$ in a humidified atmosphere of $5 \%(\mathrm{v} / \mathrm{v}) \mathrm{CO}_{2}$ in air and were cultured for evaluating the full in vitro development.

Cloned embryos were examined for cleavage and blastocyst formation rates on day 2 and 6 (the SCNT were performed on day 0), respectively. The blastocysts were fixed and stained at room temperature in $4 \%$ paraformaldehyde containing $10 \mu \mathrm{g} / \mathrm{mL}$ Hoechst 33342 for $30 \mathrm{~min}$, and then mounted on slides with glycerol. Fluorescent images were captured with a NIS Elements image system (Nikon, Tokyo, Japan) under a Nikon 50i fluorescence microscope (Nikon, Tokyo, Japan), and then processed and analyzed with Photoshop CS5 software (Adobe Systems Inc., San Jose, CA, USA).

\section{Production of SCNT derived piglets}

For generation of cloned pigs, a surgical embryo transfer was performed. Briefly, about two to three hundreds of cloned embryos were cultured 0-1 day in vitro after activation, then surgically transferred into the oviductal ampullary-isthmic junction of the surrogates exhibiting natural estrus (within 1 day of the onset of estrus) using a medical embryo transfer catheter (Weigao group, Weihai, Shandong, China). Pregnancy was diagnosed using a Honda HS-2200V veterinary ultrasound machine (Honda electronics Co., Ltd., Aichi, Japan), and surrogates were delivered by natural parturition on Day 114-120 of gestation (SCNT was performed on Day 0). Newborn piglets were taken care of by a very experienced veterinarian and were weaned at 28 days of age. The birth and weaning weight was measured and compared with contemporary piglets generated by conventional reproduction from the same pig farm.

\section{DNA parentage analysis}

For confirming the piglets were exactly cloned from the donor boar, a DNA microsatellite genotyping analysis was performed as Wei et al. (2013) described previously. Biopsies obtained from such SCNT derived piglets, donor boar

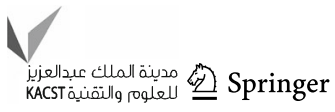


Fig. 1 Isolation of somatic fibroblasts from an adult Chinese Guike No. 1 breeding boar. a Pellets obtained by trypsin digestion of ear tissue from an adult Chinese Guike No. 1 breeding boar; $\mathbf{b}$ isolated cells adhered to the culture dish several hours after seeding; c primary fibroblasts reached confluence on day 5 ; $\mathbf{d}$ cells began to divide and proliferate 1 day after passaging; e passaged cells reached confluence and showed a typical fibroblastic morphology;

f fibroblasts suffered serum starvation cultivation were trypsinizated and used in later nuclear transfer (Scale bars $100 \mu \mathrm{m})$
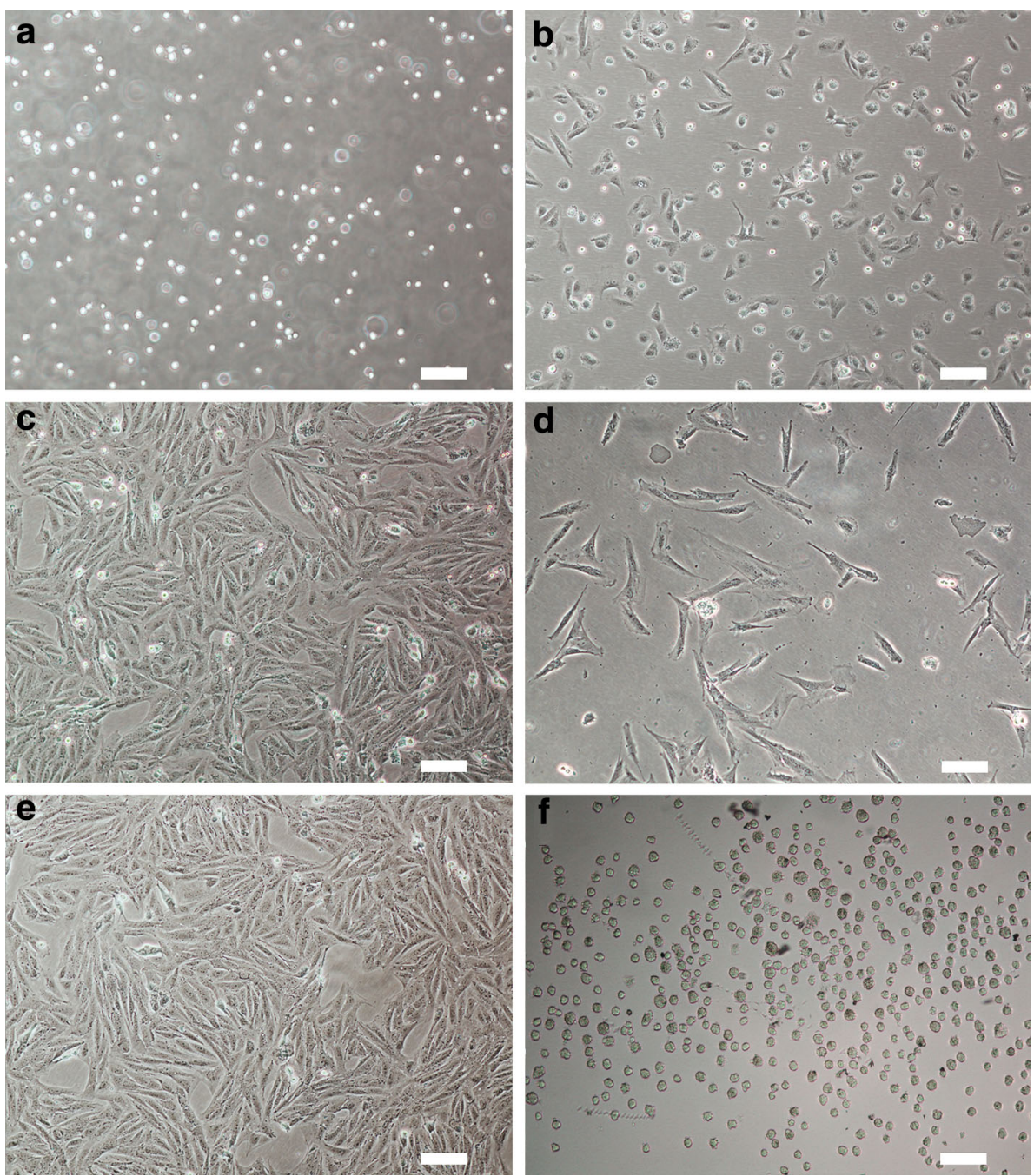

and the surrogate sows were collected and processed for isolating of genomic DNA, followed by that, it was sent to the Shanghai GeneCore BioTechnologies Co. Ltd, a widely approved professional organization for animal parentage verification. PCR primers designed for targeting ten porcinespecific microsatellite markers (S0026, S0070, S0155, S0226, SW24, SW72, SW122, SW830, SW857 and SW936) were labeled with the fluorescent dye carboxyfluorescein (FAM), followed by that, used in analysis for determining the genetic relationship among donor boar, SCNT derived piglets as well as embryo transfer surrogate recipients.

\section{Statistic analysis}

Birth and weaning weights of the nuclear transfer derived and control pigs were expressed as mean \pm standard deviation (SD) and were analyzed by $t$ test using the SPSS18.0 software (SPSS Inc., Chicago, IL, USA). Values of $P$ less than 0.05 were considered to be statistically significant.

\section{Results}

\section{Preparation of fibroblasts from the ear biopsy of an adult Chinese Guike No. 1 breeding boar}

As shown in Fig. 1a, by trypsin digestion, a large number of pellets were collected from the ear tissue, and can be adhered to the culture dish several hours after seeding (Fig. 1b). Generally, the primary cells can grow to confluence on day 5 (Fig. 1c). One day after passaging the primary cells, they began to proliferate (Fig. 1d) and three days later they can reach confluence (Fig. 1e). The rapid proliferation of these somatic cells was reflecting their high activity. In addition, as shown in Fig. 1e, almost all cells showed a typical fibroblastic morphology, such as spindle, diamond or triangle shapes, indicating they were exact highly purified fibroblasts. Overall, the fibroblasts isolated from the adult Chinese Guike No. 1 breeding boar were proliferated actively, and can be used as suitable donor cells (Fig. 1f) for nuclear transfer. 
Fig. 2 Construction and full in vitro development of cloned porcine embryos. Reconstructed porcine embryos (a) derived from the skin fibroblasts of an adult Chinese Guike No. 1 breeding boar can develop to 2-4-cell (b) and blastocyst (c; indicated by arrowheads) stage when cultivated in vitro for 2 and 6 days, respectively. $\mathbf{d}$ is showing a mounted blastocyst stained with fluorescent dye Hoechst 33342 were detected under a fluorescence microscope with UV excitation for counting the cell number. (Scale bars represented as $100 \mu \mathrm{m}$ in $\mathbf{a}-\mathbf{c}$ and $25 \mu \mathrm{m}$ in $\mathbf{d}$, respectively)
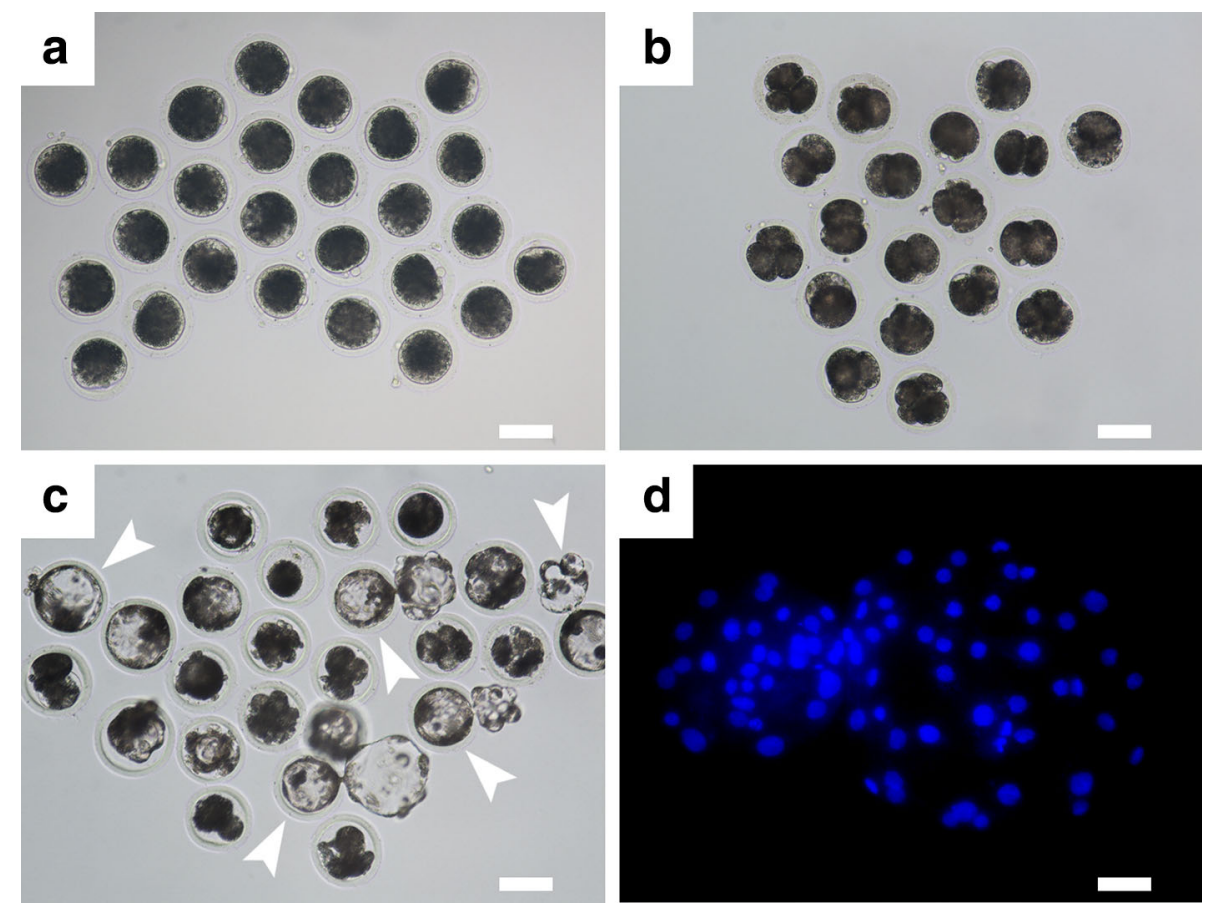

Table 1 Production of nuclear transfer derived piglets

\begin{tabular}{llllll}
\hline Recipient no. & $\begin{array}{l}\text { No. of embryos } \\
\text { transferred }\end{array}$ & $\begin{array}{l}\text { Day 40 pregnancy } \\
\text { status }^{\mathrm{a}}\end{array}$ & Gestation period (day) & $\begin{array}{l}\text { No. of piglets } \\
\text { delivered }\end{array}$ & $\begin{array}{l}\text { Cloning efficiency } \\
(\%)^{\mathrm{b}}\end{array}$ \\
\hline$\# 9032$ & 250 & + & 117 & 4 & 1.6 \\
$\# 9849$ & 256 & + & 118 & 2 & 0.8 \\
$\# 0245$ & 328 & - & - & - & - \\
$\# 4574$ & 353 & - & - & - & - \\
Total & 1187 & & & 6 & 0.5 \\
\hline
\end{tabular}

${ }^{a}$ Symbols: +, pregnant; -, not pregnant. Pregnancy was determined using a ultrasound scanning at the 40 days after embryo transfer

b Cloning efficiency: no. of piglets born/no. of embryos transferred $\times 100 \%$

\section{Construction and in vitro development of cloned porcine embryos}

As shown in Fig. 2, the cloned embryos generated from the ear fibroblasts of an adult Chinese Guike No. 1 breeding boar showed full development in vitro, namely can developed to blastocyst stage (Fig. 2c). The cleavage rate at $48 \mathrm{~h}$ post activation was $71.6 \%$ (144/201, three independent replicates), the blastocyst formation rate at 6 day post activation was $18.4 \%(37 / 201)$ and the average cell number of blastocysts was $39.0 \pm 8.5$ (mean $\pm \mathrm{SD}$, $n=20$ ). The in vitro development efficiency of such cloned embryos was comparable to our previous study aimed at the production of cloned and transgenically cloned embryos from the Huanjiang Xiang pig, which is a unique mini-pig breed originating in south China (Zhu et al. 2016).

\section{Production of SCNT derived piglets}

When 1187 reconstructed embryos in total had been transferred to four surrogate recipients, two of them became pregnant and gave birth to six live male offspring (Table 1). All of the six cloned piglets appeared normal at the birth (Fig. 3a, c) and 1 day after birth (Fig. 3b, d). The overall cloning efficiency was approximately $0.5 \%$ (6/ 1187). As shown in Table 2, the average birth and weaning weight of six piglets was $1.1 \pm 0.4$ and $6.8 \pm 1.7 \mathrm{~kg}$, respectively. There was no significant difference in birth and weaning weights between the SCNT derived piglets 
Fig. 3 Production of nuclear transfer derived piglets. Two litters of six nuclear transfer derived piglets appeared normal at the birth (a, c) and the 1 day after birth $(\mathbf{b}, \mathbf{d})$. All of the six SCNT derived piglets were clinically healthy and showed normal development at 1 month of age (e)
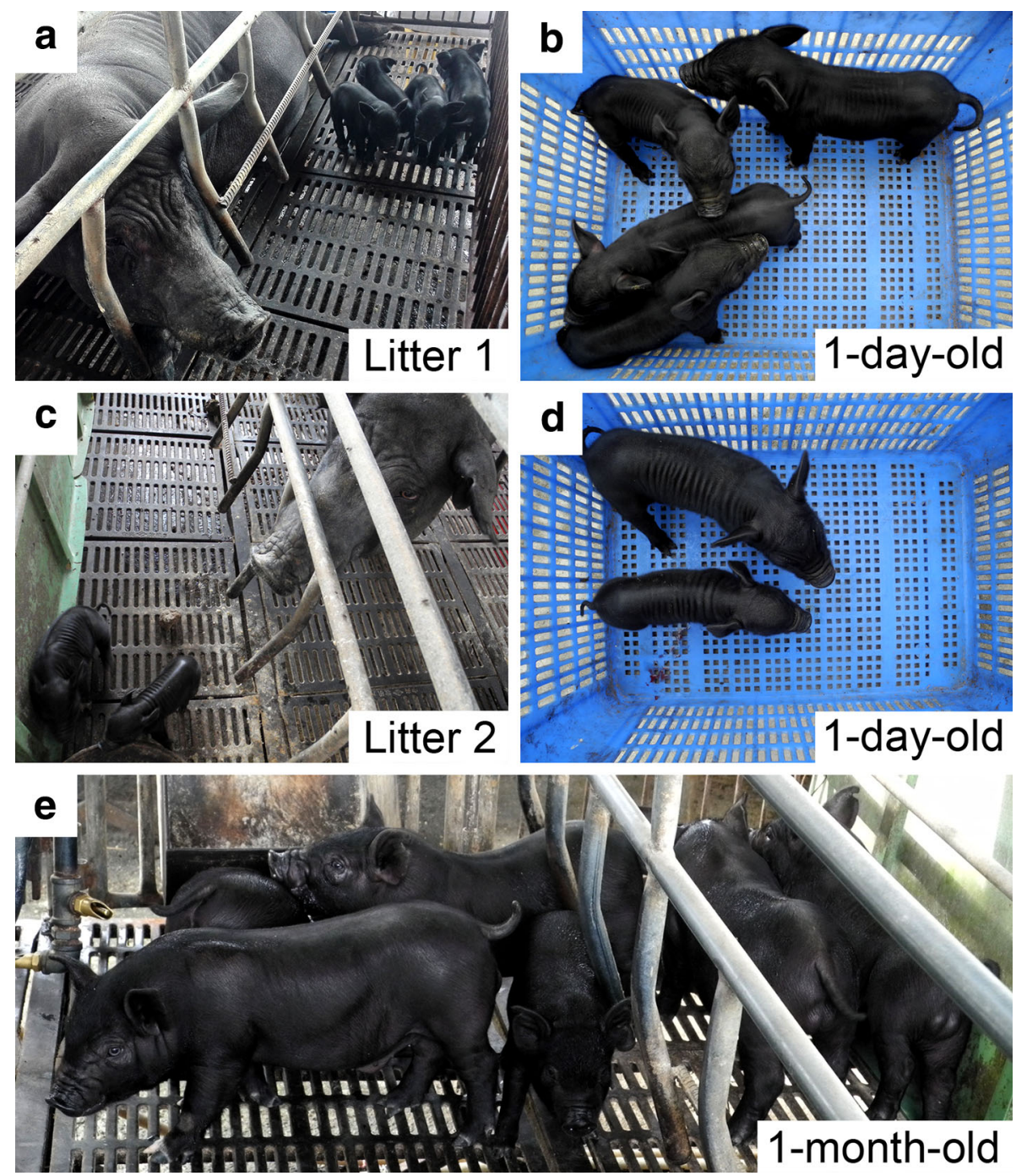

Table 2 Comparison of birth and weaning weight of nuclear transfer derived piglets with those of contemporary piglets from conventional breeding

\begin{tabular}{lll}
\hline Offspring group & Birth weight $(\mathrm{kg})^{\mathrm{a}}$ & Weaning weight $(\mathrm{kg})^{\mathrm{a}}$ \\
\hline Nuclear transfer & $1.1 \pm 0.4(n=6)$ & $6.8 \pm 1.7(n=6)$ \\
Conventional breeding & $1.2 \pm 0.3(n=64)$ & $6.1 \pm 0.9(n=54)$ \\
& $P=0.844$ & $P=0.143$ \\
\hline
\end{tabular}

${ }^{a}$ Birth and weaning weights were expressed as mean \pm standard deviation (SD) and differences between two offspring groups were analyzed by $t$ test. Values of $P$ less than 0.05 were considered to be statistically significant

and the contemporary piglets generated by conventional reproduction from the same pig farm $(1.1 \pm 0.4$ vs. $1.2 \pm 0.3$ and $6.8 \pm 1.7$ vs. $6.1 \pm 0.9$, respectively; $P>0.05$; Table 2). Furthermore, as shown in Fig. 3, all
SCNT derived piglets were clinically healthy and developed normally at birth and 1 month of age, suggesting the somatic cloning technique may be a safe and effective tool for rapid expansion of the population of Chinese Guike No. 1 pig breed.

\section{DNA parentage analysis}

DNA microsatellite genotyping analysis was performed on the SCNT derived piglets and their surrogate mothers to confirm identity to the nuclear transfer donor cells isolated from the donor adult Chinese Guike No. 1 breeding boar. As shown in Table 3, by examining with ten porcinespecific microsatellite markers, the genotype of each piglet was identical to the donor cells but different from its surrogate mother. The Fig. 4 was showing the visualized microsatellite genotyping analysis of SCNT derived offspring. 
Table 3 DNA microsatellite analysis of the nuclear transfer derived piglets

\begin{tabular}{|c|c|c|c|c|c|c|c|c|c|}
\hline \multirow[t]{2}{*}{ Microsatellite locus } & \multirow[t]{2}{*}{ Donor boar (\#200) } & \multicolumn{2}{|c|}{ Surrogate sows } & \multicolumn{4}{|c|}{ Litter 1 (from \#9032) } & \multicolumn{2}{|c|}{ Litter 2 (from \#9849) } \\
\hline & & \#9032 & \#9849 & $\# 1000$ & \#1001 & $\# 1002$ & $\# 1003$ & \#1004 & $\# 1005$ \\
\hline S00026 & $92 / 96$ & $93 / 96$ & $94 / 96$ & $92 / 96$ & $92 / 96$ & $92 / 96$ & $92 / 96$ & $92 / 96$ & $92 / 96$ \\
\hline S00070 & $277 / 285$ & $278 / 283$ & $275 / 283$ & $277 / 285$ & $277 / 285$ & $277 / 285$ & $277 / 285$ & $277 / 285$ & $277 / 285$ \\
\hline S00155 & $158 / 160$ & $152 / 158$ & $152 / 160$ & $158 / 160$ & $158 / 160$ & $158 / 160$ & $158 / 160$ & $158 / 160$ & $158 / 160$ \\
\hline S00226 & $179 / 194$ & $178 / 207$ & $178 / 192$ & $179 / 194$ & $179 / 194$ & $179 / 194$ & $179 / 194$ & $179 / 194$ & $179 / 194$ \\
\hline SW024 & $102 / 109$ & $115 / 121$ & $109 / 115$ & $102 / 109$ & $102 / 109$ & $102 / 109$ & $102 / 109$ & $102 / 109$ & $102 / 109$ \\
\hline SW072 & $111 / 115$ & $96 / 98$ & $110 / 114$ & $111 / 115$ & $111 / 115$ & $111 / 115$ & $111 / 115$ & $111 / 115$ & $111 / 115$ \\
\hline SW122 & 110 & $109 / 111$ & $82 / 87$ & 110 & 110 & 110 & 110 & 110 & 110 \\
\hline SW830 & $180 / 182$ & $178 / 184$ & $179 / 181$ & $180 / 182$ & $180 / 182$ & $180 / 182$ & $180 / 182$ & $180 / 182$ & 180/182 \\
\hline SW857 & $149 / 153$ & $148 / 155$ & $150 / 155$ & $149 / 153$ & $149 / 153$ & $149 / 153$ & $149 / 153$ & $149 / 153$ & $149 / 153$ \\
\hline SW936 & $107 / 109$ & $100 / 110$ & $102 / 110$ & $107 / 109$ & $107 / 109$ & $107 / 109$ & $107 / 109$ & $107 / 109$ & $107 / 109$ \\
\hline
\end{tabular}

For each microsatellite locus, the genotype was determined by size (in base pairs). Two numbers are shown for each sample at each locus represent the PCR product size for each of the two alleles at that particular locus. Litter 1 and 2 were delivered from the surrogate sow \#9032 and \#9849, respectively

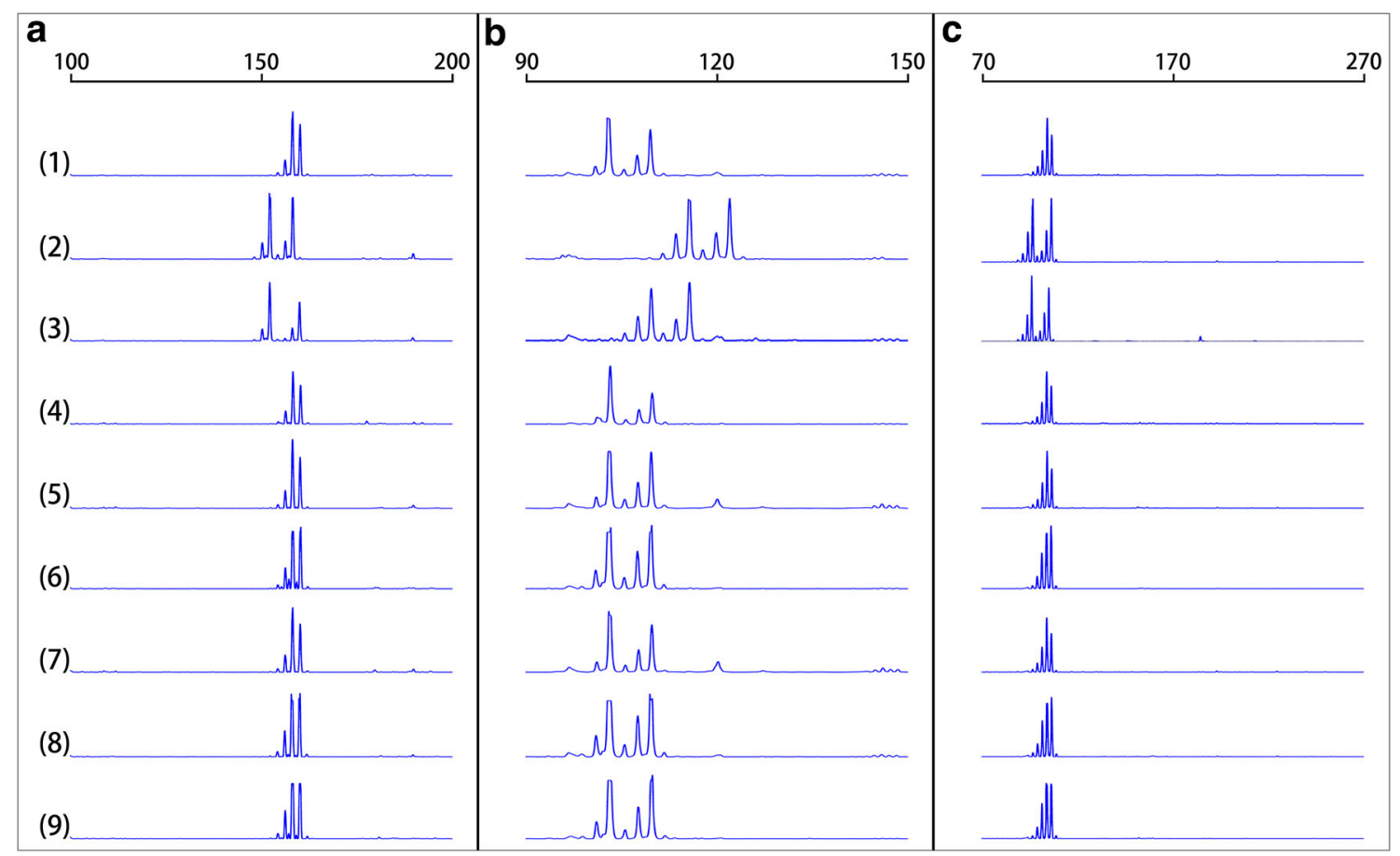

Fig. 4 Representative PCR analyses of microsatellite loci. The representative electropherograms represent analyses of three randomly selected microsatellite loci (S00155, SW024 and SW936) in genomic DNA from the donor boar (1), surrogate sow \#9032 (2), surrogate sow \#9849 (3), as well as the six nuclear transfer derived

\section{Discussion}

As described above, we successfully produced six healthy cloned male piglets using the ear fibroblasts of an adult breeding boar from the novel Chinese Guike No. 1 swine specialized strain with superior production performance. offspring (4-9). Each panel shows data for a randomly selected microsatellite-specific primer pair: S00155 (a), SW024 (b) and SW936 (c). Traces were produced on an ABI 3730 DNA analyzer (Applied Biosystems, Foster City, CA, USA). The calculated sizes (in base pairs) are displayed at the top of the traces

However, the overall cloning efficiency was only $0.5 \%$, which was inferior to those in previous studies carried out by other groups (Walker et al. 2002; Zhao et al. 2009, 2010a; Richter et al. 2012; Rim et al. 2013; Huang et al. 2012; Kurome et al. 2013; Callesen et al. 2014; Liu et al. 2015). Such low output of cloned pigs could be 
largely attributed to the low quality of the transferred cloned embryos generated by reconstruction of enucleated in vitro-matured oocytes with somatic cell nuclei. There is a widespread consensus that the SCNT derived porcine embryos are less ideal than embryos obtained in vivo and even produced via in vitro fertilization (IVF), owing to their lower developmental competence (Vajta and Gjerris 2006; Vajta et al. 2007). For example, as is described above, the blastocyst formation rate of cloned porcine embryos constructed in our laboratory was only $18.4 \%$ (37/201, three independent replicates), while the data from IVF embryos is usually as high as more than $50 \%$ (Yoshioka et al. 2008; Yoshioka 2011; Misumi et al. 2014). Furthermore, in the pig, there is an additional difficulty that at least four good quality embryos are required to initiate and maintain a pregnancy in the surrogate sow (Polge et al. 1966), therefore, the SCNT derived porcine embryos with poor developmental competence may certainly result in a poor outcome of cloned pigs.

Investigations have been addressed that the developmental competences of porcine SCNT-derived embryos are affected by a large number of factors. Among them, an important role seems to be played by the quality of in vitromatured pig oocytes used as nuclear recipient cells (DangNguyen et al. 2011; Ju and Rui 2012; Pribenszky et al. 2012; Alvarez et al. 2015), different approaches to SCNT procedures (Samiec et al. 2003, 2012; Li et al. 2004; Nánássy et al. 2008; Samiec and Skrzyszowska 2010b, 2012b, 2014a) as well as the systems applied to in vitro embryo culture (Nánássy et al. 2008; Yoshioka et al. 2008; Yoshioka 2011). In addition, evidences also suggest the nuclear donor cell type plays a pivotal role in pig cloning (Hao et al. 2009; Lee et al. 2010; Samiec and Skrzyszowska 2010a; Richter et al. 2012; Fan et al. 2013; Wei et al. 2013; Liu et al. 2014, 2015; Samiec et al. 2015). In this study, we used the ear skin fibroblasts isolated from an adult breeding boar as donor cells for producing cloned embryos. In spite of the successful use of such adult somatic cells for production of cloned pigs (Polejaeva et al. 2000; Richter et al. 2012; Wei et al. 2013; Liu et al. 2015), the overall SCNT efficiency in this mammalian species has been reported to be compromised. For example, when Zhao et al. (2009) tried to clone National Institutes of Health (NIH) miniature pigs with definite swine leukocyte antigen (SLA) using adult ear fibroblast cells as SCNT donor cells, none of the six surrogate recipients established a pregnancy. Moreover, the limited pre- and post-implantation developmental potential of porcine and other mammalian species cloned embryos can be biased to a large extent by the incompatibility in an intergenomic communication between donor cell-inherited nuclear DNA, donor cell-descended mitochondrial DNA (mtDNA) fractions and recipient oocyte-derived mtDNA molecules (Samiec 2005a, b; Yan et al. 2010, 2011; Srirattana et al. 2011). Although the exact mechanisms underlying the epigenetic remodeling and reprogramming of somatic cell nuclei in a cytoplasm of both reconstructed oocytes and descendant blastomeres of resultant cloned embryos are still unclear, increasing lines of evidence suggest that improper or incomplete epigenetic modifications of donor nuclear genome, such as DNA methylation and histone acetylation, are closely associated with the low overall efficiency of pig cloning (Zhao et al. 2010b; Whitworth and Prather 2011; Lee and Prather 2013, 2014). Up to now, several types of epigenetic drugs, such as non-specific DNA methyltransferase inhibitors (e.g., 5-aza-2'-deoxycytidine) and nonspecific histone deacetylase inhibitors (e.g., trichostatin A, scriptaid and oxamflatin), have been used for epigenomic transformation of in vitro cultured nuclear donor cells, in vitro maturing nuclear recipient oocytes and activated nuclear-transferred oocytes, resulting in not only significant enhancement of the in vitro developmental capacity of porcine cloned embryos (Himaki et al. 2010; Mao et al. 2012, 2015; Ning et al. 2012; Park et al. 2012; Samiec and Skrzyszowska 2010c, 2011, 2012a, 2014b; Xu et al. 2013; Zhou et al. 2013; Cong et al. 2013; Bohrer et al. 2014; Luo et al. 2014; Liang et al. 2015; Samiec et al. 2015; Whitworth et al. 2015), but also the improvement in the efficiency of generating viable cloned offspring in pigs (Zhao et al. 2009, 2010a). Thus, such successful strategy can be used in our future work for producing cloned pigs with a higher efficiency.

Besides the disappointingly low overall efficiency of pig cloning, the frequent developmental abnormalities exhibited by SCNT-derived offspring have been considered as another major cause which hinders the wide application of such emerging assisted reproductive technology (ART) in pig production and breeding (Vajta et al. 2007). Several cloned piglets have been observed with abnormalities, for instance, lacking an anus and tail (Walker et al. 2002), malformations showed by some important organs (Schmidt et al. 2011; Park et al. 2007, 2010), as well as smaller birth size and lower growth rate (Jiang et al. 2007). As has been demonstrated so far, such cloned pigs with severe developmental abnormalities displayed considerable dysregulation in the expression of both nuclear DNA- and mitochondrial DNA-inherited genes (Jiang et al. 2007; Park et al. 2007, 2010, 2015), which may be attributed to the incorrect somatic cell nuclear reprogramming, the variable epigenetic regulation and the deficiencies in the mitochondrial function occurring in a cytoplasm of recipient oocytes (Tian et al. 2008; Park et al. 2015). In the present study, all of the six cloned piglets showed normal health at birth and 1 month of age. In addition, their birth and weaning weights were comparable to that of controls from conventional breeding, suggesting such cloned 
Chinese Guike No. 1 piglets have a normal growth. However, the above mentioned dysregulation in gene expression and the real epigenetic status should be further tested for understanding the detail of cloned piglets at molecular level.

In summary, the present study successfully produced six healthy cloned piglets from the ear fibroblasts of an adult Chinese Guike No. 1 breeding boar. The overall cloning efficiency was $0.5 \%$. All of the cloned piglets were clinically healthy and had a normal weight at birth and weaning. Substantial application of the somatic cloning technique in the production and extension of Chinese Guike No. 1 breeding boars needs to persistently monitor the health and development of the cloned piglets (Liu et al. 2010; $\mathrm{Hu}$ et al. 2012). More importantly, the superior production performance seen in their clonal provenance should also be evaluated whether could be displayed when the cloned piglets reached their adulthood (Hu et al. 2012), and such study has already been scheduled into our future research work.

Acknowledgments The authors would like to express their thanks and appreciation to veterinarian Nangan Liu for his excellent veterinary assistance. This work was supported by the National Natural Science Foundation of China (Grant No. 31260553), the Open Projects of Guangxi Key Laboratory of Livestock Genetic Improvement (Grant No. 2014GXKLLGI-08), and the Graduate Programs for Innovational Research funded by Guangxi Department of Education (Grant No. YCSZ2013003). The manuscript was polished by the LetPub.

\section{Compliance with ethical standards}

Conflict of interest The authors declare that they have no conflict of interests.

Open Access This article is distributed under the terms of the Creative Commons Attribution 4.0 International License (http:// creativecommons.org/licenses/by/4.0/), which permits unrestricted use, distribution, and reproduction in any medium, provided you give appropriate credit to the original author(s) and the source, provide a link to the Creative Commons license, and indicate if changes were made.

\section{References}

Alvarez GM, Morado SA, Soto MP, Dalvit GC, Cetica PD (2015) The control of reactive oxygen species influences porcine oocyte in vitro maturation. Reprod Dom Anim 50:200-205

Betthauser J, Forsberg E, Augenstein M, Childs L, Eilertsen K, Enos J, Forsythe T, Golueke P, Jurgella G, Koppang R, Lesmeister T, Mallon K, Mell G, Misica P, Pace M, Pfister-Genskow M, Strelchenko N, Voelker G, Watt S, Thompson S, Bishop M (2000) Production of cloned pigs from in vitro systems. Nat Biotechnol 18:1055-1059

Bohrer RC, Duggavathi R, Bordignon V (2014) Inhibition of histone deacetylases enhances DNA damage repair in SCNT embryos. Cell Cycle 13:2138-2148
Callesen H, Liu Y, Pedersen HS, Li R, Schmidt M (2014) Increasing efficiency in production of cloned piglets. Cell Reprogr $16: 407-410$

Cong PQ, Zhu KJ, Ji QQ, Zhao HJ, Chen YS (2013) Effects of trichostatin $\mathrm{A}$ on histone acetylation and methylation characteristics in early porcine embryos after somatic cell nuclear transfer. Anim Sci J 84:639-649

Dang-Nguyen TQ, Somfai T, Haraguchi S, Kikuchi K, Tajima A, Kanai Y, Nagai T (2011) In vitro production of porcine embryos: current status, future perspectives and alternative applications. Anim Sci J 82:374-382

Fan NN, Chen JJ, Shang ZC, Dou HW, Ji GZ, Zou QJ, Wu L, He L, Wang F, Liu K, Liu N, Han J, Zhou Q, Pan D, Yang D, Zhao B, Ouyang Z, Liu Z, Zhao Y, Lin L, Zhong C, Wang Q, Wang S, Xu Y, Luan J, Liang Y, Yang Z, Li J, Lu C, Vajta G, Li Z, Ouyang H, Wang H, Wang Y, Yang Y, Liu Z, Wei H, Luan Z, Esteban MA, Deng H, Yang H, Pei D, Li N, Pei G, Liu L, Du Y, Xiao L, Lai L (2013) Piglets cloned from induced pluripotent stem cells. Cell Res 23:162-166

Fang M, Hu X, Jiang T, Braunschweig M, Hu L, Du Z, Feng J, Zhang Q, Wu C, Li N (2004) The phylogeny of Chinese indigenous pig breeds inferred from microsatellite markers. Anim Genet 36:7-13

Galli C, Lagutina I, Perota A, Colleoni S, Duchi R, Lucchini F, Lazzari G (2012) Somatic cell nuclear transfer and transgenesis in large animals: current and future insights. Reprod Dom Anim 47(Suppl. 3):2-11

Gurdon JB, Wilmut I (2011) Nuclear transfer to eggs and oocytes. CSH Perspect Biol 3:a002659

Hao YH, Wax D, Zhong ZS, Murphy C, Ross JW, Rieke A, Samuel M, Spate L, Dyce P, Li JL, Sutovsky P, Prather RS (2009) Porcine skin-derived stem cells can serve as donor cells for nuclear transfer. Cloning Stem Cells 11:101-109

Himaki T, Yokomine T, Sato M, Takao S, Miyoshi K, Yoshida M (2010) Effects of trichostatin A on in vitro development and transgene function in somatic cell nuclear transfer embryos derived from transgenic Clawn miniature pig cells. Anim Sci J 81:558-563

Hu K, Kong QR, Zhao ZP, Lu XY, Liu B, Li YT, Wang H, Liu ZH (2012) Assessment of reproduction and growth performance of offspring derived from somatic cell cloned pigs. Anim Sci J 83:639-643

Huang YY, Ouyang HS, Yu H, Lai LX, Pang DX, Li ZJ (2012) Efficiency of porcine somatic cell nuclear transfer-a retrospective study of factors related to embryo recipient and embryos transferred. Biol Open 2:1223-1228

Jiang L, Jobst P, Lai LX, Samuel M, Ayares D, Prather RS, Tian CXC (2007) Expression levels of growth-regulating imprinted genes in cloned piglets. Cloning Stem Cells 9:97-106

Ju S, Rui R (2012) Effects of cumulus cells on in vitro maturation of oocytes and development of cloned embryos in the pig. Reprod Dom Anim 47:521-529

Kurome M, Geistlinger L, Kessler B, Zakhartchenko V, Klymiuk N, Wuensch A, Richter A, Baehr A, Kraehe K, Burkhardt K, Flisikowski K, Flisikowska T, Merkl C, Landmann M, Durkovic M, Tschukes A, Kraner S, Schindelhauer D, Petri T, Kind A, Nagashima H, Schnieke A, Zimmer R, Wolf E (2013) Factors influencing the efficiency of generating genetically engineered pigs by nuclear transfer: multi-factorial analysis of a large data set. BMC Biotechnol 13:43

Lee K, Prather RS (2013) Advancements in somatic cell nuclear transfer and future perspectives. Anim Front 3:56-61

Lee K, Prather RS (2014) Cloning pigs by somatic cell nuclear transfer. In: Cibelli J, Gurdon J, Wilmut I, Jaenisch R, Lanza R, West MD, Campbell KHS (eds) Principles of cloning, 2nd edn. Elsevier Inc., San Diego, pp 245-254 
Lee SL, Kang EJ, Maeng GH, Kim MJ, Park JK, Kim TS, Hyun SH, Lee ES, Rho GJ (2010) Developmental ability of miniature pig embryos cloned with mesenchymal stem cells. J Reprod Develop $56: 256-262$

Li GP, White KL, Bunch TD (2004) Review of enucleation methods and procedures used in animal cloning: state of the art. Cloning Stem Cells 6:5-13

Liang S, Zhao MH, Choi JW, Kim NY, Cui XS (2015) Scriptaid treatment decreases DNA methyltransferase 1 expression by induction of microRNA-152 expression in porcine somatic cell nuclear transfer embryos. PLoS One 10:e0134567

Liu HB, Lv PR, Yang XG, Qin XE, Pi DY, Lu YQ, Lu KH, Lu SS, Li DS (2009) Fibroblasts from the new-born male testicle of Guangxi Bama mini-pig (Sus scrofa) can support nuclear transferred embryo development in vitro. Zygote 17:147-156

Liu HB, Lv PR, He RG, Yang XG, Pan TB, Huang GY, Huang MR, Lu YQ, Lu SS, Li DS, Lu KH (2010) Cloned Guangxi Bama minipig (Sus scrofa) and its offspring have normal reproductive performance. Cell Reprogram 12:543-550

Liu HB, Lv PR, Zhu XX, Wang XW, Yang XG, Zuo EW, Lu YQ, Lu SS, Lu KH (2014) In vitro development of porcine transgenic nuclear-transferred embryos derived from new-born Guangxi Bama mini-pig kidney fibroblasts. In Vitro Cell Dev Biol Anim 50:811-821

Liu TB, Dou HW, Xiang X, Li L, Li Y, Lin L, Pang X, Zhang Y, Chen Y, Luan J, Xu Y, Yang Z, Yang W, Liu H, Li F, Wang H, Yang H, Bolund L, Vajta G, Du Y (2015) Factors determining the efficiency of porcine somatic cell nuclear transfer: data analysis with over 200,000 reconstructed embryos. Cell Reprogr 17:463-471

Luo BP, Ju SQ, Muneri CW, Rui R (2014) Effects of histone acetylation status on the early development of in vitro porcine transgenic cloned embryos. Cell Reprogr 17:41-48

Mao JD, Tessanne K, Whitworth KM, Spate LD, Walters EM, Samuel MS, Murphy CN, Tracy L, Zhao J, Prather RS (2012) Effects of combined treatment of MG132 and Scriptaid on early and term development of porcine somatic cell nuclear transfer embryos. Cell Reprogr 14:385-389

Mao JD, Zhao MT, Whitworth KM, Spate LD, Walters EM, O'Gorman C, Lee K, Samuel MS, Murphy CN, Wells K, Rivera RM, Prather RS (2015) Oxamflatin treatment enhances cloned porcine embryo development and nuclear reprogramming. Cell Reprogr 17:28-40

Misumi K, Hirayama Y, Suzuki M, Nakai M, Kaneko H, Noguchi J, Kikuchi K (2014) Production of middle white piglets after transfer of embryos produced in vitro. J Reprod Develop 60:246-249

Nánássy L, Lee K, Jávor A, Macháty Z (2008) Effects of activation methods and culture conditions on development of parthenogenetic porcine embryos. Anim Reprod Sci 104:264-274

Niemann H, Lucas-Hahn A (2012) Somatic cell nuclear transfer cloning: practical applications and current legislation. Reprod Domest Anim 47(Suppl. 5):2-10

Ning SF, Li QY, Liang MM, Yang XG, Xu HY, Lu YQ, Lu SS, Lu KH (2012) Methylation characteristics and developmental potential of Guangxi Bama minipig (Sus scrofa domestica) cloned embryos from donor cells treated with trichostatin A and 5-aza-2'-deoxycytidine. Zygote 21:178-186

Onishi A, Iwamoto M, Akita T, Mikawa S, Takeda K, Awata T, Hanada H, Perry AC (2000) Pig cloning by microinjection of fetal fibroblast nuclei. Science 289:1188-1190

Park JH, Smith S, Lai LX, Samuel M, Wax D, Prather RS, Yang XZ, Tian CXC (2007) Expression profiles of brain, kidney, and lung of cloned pigs. Biol Reprod 77:237

Park JH, Marjani SL, Lai LX, Samuel M, Wax D, Bruno RS, Prather RS, Yang XZ, Tian CXC (2010) Altered gene expression profiles in the brain, kidney, and lung of deceased neonatal cloned pigs. Cell Reprogr 12:589-597

Park SJ, Park HJ, Koo OJ, Choi WJ, Moon JH, Kwon DK, Kang JT, Kim S, Choi JY, Jang G, Lee BC (2012) Oxamflatin improves developmental competence of porcine somatic cell nuclear transfer embryos. Cell Reprogr 14:398-406

Park JH, Lai LX, Samuel M, Wax D, Prather RS, Tian CXC (2015) Disruption of mitochondrion-to-nucleus interaction in deceased cloned piglets. PLoS One 10:e0129378

Polejaeva IA, Chen SH, Vaught TD, Page RL, Mullins J, Ball S, Dai Y, Boone J, Walker S, Ayares DL, Colman A, Campbell KH (2000) Cloned pigs produced by nuclear transfer from adult somatic cells. Nature 407:86-90

Polge C, Rowson LE, Chang MC (1966) The effect of reducing the number of embryos during early stages of gestation on the maintenance of pregnancy in the pig. J Reprod Fertil 12:395-397

Pribenszky C, Lin L, Du Y, Losonczi E, Dinnyes A, Vajta G (2012) Controlled stress improves oocyte performance-cell preconditioning in assisted reproduction. Reprod Dom Anim 47(Suppl. 4):197-206

Richter A, Kurome M, Kessler B, Zakhartchenko V, Klymiuk N, Nagashima H, Wolf E, Wuensch A (2012) Potential of primary kidney cells for somatic cell nuclear transfer mediated transgenesis in pig. BMC Biotechnol 12:84

Rim CH, Fu ZX, Bao L, Chen HD, Zhang D, Luo Q, Ri HC, Huang H, Luan Z, Zhang Y, Cui C, Xiao L, Jong UM (2013) The effect of the number of transferred embryos, the interval between nuclear transfer and embryo transfer, and the transfer pattern on pig cloning efficiency. Anim Reprod Sci 143:91-96

Samiec M (2005a) The role of mitochondrial genome (mtDNA) in somatic and embryo cloning of mammals. A review. J Anim Feed Sci 14:213-233

Samiec M (2005b) The effect of mitochondrial genome on architectural remodeling and epigenetic reprogramming of donor cell nuclei in mammalian nuclear transfer-derived embryos. J Anim Feed Sci 14:393-422

Samiec M, Skrzyszowska M (2010a) Preimplantation developmental capability of cloned pig embryos derived from different types of nuclear donor somatic cells. Ann Anim Sci 10:385-398

Samiec M, Skrzyszowska M (2010b) The use of different methods of oocyte activation for generation of porcine fibroblast cell nuclear-transferred embryos. Ann Anim Sci 10:399-411

Samiec M, Skrzyszowska M (2010c) High developmental capacity of cloned pig embryos following trichostatin A-mediated epigenomic modulation throughout in vitro maturation of oocytes pretreated with roscovitine. Reprod Domest Anim 45(Suppl. 3):106

Samiec M, Skrzyszowska M (2011) In vitro development of nucleartransferred pig embryos following use of trichostatin A for epigenetic transformation of both recipient oocytes and nuclear donor somatic cells. Reprod Domest Anim 46(Suppl. 3):146

Samiec M, Skrzyszowska M (2012a) High developmental capability of porcine cloned embryos following trichostatin A-dependent epigenomic transformation during in vitro maturation of oocytes pre-exposed to R-roscovitine. Anim Sci Pap Rep 30:383-393

Samiec M, Skrzyszowska M (2012b) Roscovitine is a novel agent that can be used for the activation of porcine oocytes reconstructed with adult cutaneous or fetal fibroblast cell nuclei. Theriogenology $78: 1855-1867$

Samiec M, Skrzyszowska M (2014a) Biological transcomplementary activation as a novel and effective strategy applied to the generation of porcine somatic cell cloned embryos. Reprod Biol 14:128-139

Samiec M, Skrzyszowska M (2014b) Trichostatin A-dependent epigenetic modulation of in vitro-maturing pig oocytes subjected to subsequent reconstruction with fetal fibroblast cell nuclei. Reprod Biol 13(Suppl. 5):11-12 
Samiec M, Skrzyszowska M, Smorag Z (2003) Effect of activation treatments on the in vitro developmental potential of porcine nuclear transfer embryos. Czech J Anim Sci 48:499-507

Samiec M, Skrzyszowska M, Lipiński D (2012) Pseudophysiological transcomplementary activation of reconstructed oocytes as a highly efficient method used for producing nuclear-transferred pig embryos originating from transgenic foetal fibroblast cells. Pol J Vet Sci 15:509-516

Samiec M, Opiela J, Lipiński D, Romanek J (2015) Trichostatin A-mediated epigenetic transformation of adult bone marrowderived mesenchymal stem cells biases the in vitro developmental capability, quality, and pluripotency extent of porcine cloned embryos. BioMed Res Int 2015:814686

Schmidt M, Winter KD, Li J, Kragh PM, Du YT, Lin L (2011) Malformations found by autopsy of cloned and transgenic piglets of different breeds. Reprod Fert Develop 24:123

Srirattana K, Matsukawa K, Akagi S, Tasai M, Tagami T, Nirasawa K, Nagai T, Kanai Y, Parnpai R, Takeda K (2011) Constant transmission of mitochondrial DNA in intergeneric cloned embryos reconstructed from swamp buffalo fibroblasts and bovine ooplasm. Anim Sci J 82:236-243

Tian CXC, Park J, Bruno R, French R, Jiang L, Prather RS (2008) Altered gene expression in cloned piglets. Reprod Fert Dev 21:60-66

Vajta G, Gjerris M (2006) Science and technology of farm animal cloning: state of the art. Anim Reprod Sci 92:211-230

Vajta G, Zhang YH, Macháty Z (2007) Somatic cell nuclear transfer in pigs: recent achievements and future possibilities. Reprod Fert Dev 19:403-423

Walker SC, Shin T, Zaunbrecher GM, Romano JE, Johnson GA, Bazer FW, Piedrahita JA (2002) A highly efficient method for porcine cloning by nuclear transfer using in vitro-matured oocytes. Cloning Stem Cells 4:105-112

Wang YN, Tang ZL, Sun YQ, Wang HY, Wang C, Yu SB, Liu J, Zhang Y, Fan B, Li K, Liu B (2014) Analysis of genome-wide copy number variations in Chinese indigenous and western pig breeds by $60 \mathrm{~K}$ SNP genotyping arrays. PLoS One 9:e106780

Wei HJ, Qing YB, Pan WR, Zhao HY, Li HH, Cheng WM, Zhao L, Xu C, Li H, Li S, Ye L, Wei T, Li X, Fu G, Li W, Xin J, Zeng YZ (2013) Comparison of the efficiency of Banna miniature inbred pig somatic cell nuclear transfer among different donor cells. PLoS One 8:e57728

Whitworth KM, Prather RS (2011) Somatic cell nuclear transfer efficiency: how can it be improved through nuclear remodeling and reprogramming? Mol Reprod Dev 77:1001-1015

Whitworth KM, Mao JD, Lee K, Spollen WG, Samuel MS, Walters EM, Spate LD, Prather RS (2015) Transcriptome analysis of pig in vivo, in vitro-fertilized, and nuclear transfer blastocyst-stage embryos treated with histone deacetylase inhibitors postfusion and activation reveals changes in the lysosomal pathway. Cell Reprogr 17:243-258

Whyte JJ, Prather RS (2011) Genetic modifications of pigs for medicine and agriculture. Mol Reprod Dev 78:879-891
Wilmut I, Beaujean N, de Sousa PA, Dinnyes A, King TJ, Paterson LA, Wells DN, Young LE (2002) Somatic cell nuclear transfer. Nature 419:583-586

Xu WH, Li ZC, Yu B, He XY, Shi JS, Zhou R, Liu DW, Wu ZF (2013) Effects of DNMT1 and HDAC inhibitors on gene-specific methylation reprogramming during porcine somatic cell nuclear transfer. PLoS One 8:e64705

Yan ZH, Zhou YY, Fu J, Jiao F, Zhao LW, Guan PF, Huang SZ, Zeng YT, Zeng F (2010) Donor-host mitochondrial compatibility improves efficiency of bovine somatic cell nuclear transfer. BMC Dev Biol 10:31

Yan H, Yan Z, Ma Q, Jiao F, Huang S, Zeng F, Zeng Y (2011) Association between mitochondrial DNA haplotype compatibility and increased efficiency of bovine intersubspecies cloning. J Genet Genom 38:21-28

Yang CG, Ren J, Guo YM, Ding NS, Chen CY, Huang LS (2006) Genetic evidence for the origin of an IGF2 quantitative trait nucleotide in Chinese pigs. Anim Genet 37:179-180

Yoshioka K (2011) Development and application of a chemically defined medium for the in vitro production of porcine embryos. J Reprod Dev 57:9-16

Yoshioka K, Suzuki C, Onishi A (2008) Defined system for in vitro production of porcine embryos using a single basic medium. J Reprod Dev 54:208-213

Zhao JG, Ross JW, Hao YH, Spate LD, Walters EM, Samuel MS, Rieke A, Murphy CN, Prather RS (2009) Significant improvement in cloning efficiency of an inbred miniature pig by histone deacetylase inhibitor treatment after somatic cell nuclear transfer. Biol Reprod 81:525-530

Zhao JG, Hao YH, Ross JW, Spate LD, Walters EM, Samuel MS, Rieke A, Murphy CN, Prather RS (2010a) Histone deacetylase inhibitors improve in vitro and in vivo developmental competence of somatic cell nuclear transfer porcine embryos. Cell Reprogr 12:75-83

Zhao JG, Whyte J, Prather RS (2010b) Effect of epigenetic regulation during swine embryogenesis and on cloning by nuclear transfer. Cell Tissue Res 341:13-21

Zhou Y, Huang YY, Xie WH, Song Q, Ji Y, Zhang YP, Ouyang HS, Lai LX, Pang DX, Tang XC (2013) Scriptaid affects histone acetylation and the expression of development-related genes at different stages of porcine somatic cell nuclear transfer embryo during early development. Chin Sci Bull 58:2044-2052

Zhu XX, Quan SN, Zeng YL, Huang Y, Sun RY, Lu KH, Lu SS (2014) Efficient establishment of Guangxi Bama mini-pig transgenic fibroblasts via Xfect polymer transfection. Rom Biotech Lett 19:9883-9890

Zhu XX, Nie JY, Quan SN, Xu HY, Yang XG, Lu YQ, Lu KH, Lu SS (2016) In vitro production of cloned and transgenically cloned embryos from Guangxi Huanjiang Xiang pig. In Vitro Cell Dev Biol Anim 52:137-143 